\section{ФОРМИРОВАНИЕ МОДЕЛИ КЛАССИФИКАЦИИ ГОСУДАРСТВЕННОГО АУДИТА}

Отражены результаты сравнительного анализа существующих классификаций государственного аудита. Исследована обоснованность его идентификации как формы и вида контроля. Уточнено толкование понятий «форма контроля», «вид контроля», «подвид контроля». На основании осознания полиморфности государственного аудита доказана целесообразность его признание формой контроля, а также осуществлена их классификация.

Ключевые слова: государственный аудит, форма контроля, вид контроля, классификация государственного аудита.
Баранюк Юрій Романович, голова Наукового товариства студентів, аспірантів, докторантів та молодих вчених, кафедра фінансового аудиту, Київський національний торговельно-економічний університет, Україна.

Бардаи Сергей Владимирович, доктор экономических наук, профессор, заведующий кафедрой финансов, банковского дела и страхования, Киевский кооперативный институт бизнеса и права, Украина.

Баранюк Юрий Романович, председатель Научного общества студентов, аспирантов, докторантов и молодых ученых, кафедра финансового аудита, Киевский национальный торговоэкономический университет, Украина.

Bardash Serhii, Kyiv Cooperative Institute of Business and Law, Ukraine, e-mail: serg.bardash@gmail.com

Baraniuk Yurii, Kyiv National University of Trade and Economics, Ukraine
Бардаш Сергій Володимирович, доктор економічних наук страхування, Київський кооперативний інститут бізнесу і права,

Україна, e-mail: serg.bardash@gmail.com

\section{Yarygina I., O'Malley P.}

\title{
THE CORPORATE FAILURE PREDICTION CAPABILITIES OF PRIVATE NON- MANUFACTURING COMPANIES
}

У роботі виявлені можливості використання скорингових моделей Альтмана і Олсона з метою прогнозу банкрутства невиробничих компаній в горизонті операційного періоду 1-4 роки. Дослідження розкриває особливості застосування зазначених моделей з метою оцінки стійкості компаній.

Ключові слова: модель Альтмана Z-скоринг, модель Олсона О-скоринг, невиробничі компанії, банкрутство корпоращії.

\section{Introduction}

The study assess the prediction capabilities of the Altman Z-Score Private Firm Model and the Ohslon O-Score Model to see whether either has merit in the above mentioned prediction. The data and company financials that are used to conduct the study were obtained from the Bureau Van Dijk «FAME» database, which offers substantial company information on private companies. The companies that were selected for this study had to meet the below criteria: the company had to be listed as a privately owned company, the company could not be defined as operating in manufacturing, selected firms were required to have at least four years of full financial records.According to the general approach, the Z-score formula for predicting bankruptcy was published in 1968 by Edward I. Altman, who was, at the time, an Assistant Professor of Finance at New York University [1]. The formula may be usedto predict the probability that a firm will go into bankruptcy within two years. Z-scores are used to predict corporate defaults and an easy-to-calculate control measure for the financial distress status of companies in academic studies. The Z-score uses multiple corporate income and balance sheet values to measure the financial health of a company. At the same time the Ohlson O-Score for predicting bankruptcy is a multi-factor financial formula postulated in 1980 by Dr. James Ohlson of the
New York University Stern Accounting Department [2] as an alternative to the Altman Z-score for predicting financial distress.

\section{The object of research and its technological audit}

This study has been undertaken to analyze the predictive capabilities of the Altman Z-Score Private Firm Model and Ohlson O-Score Model upon modern day private non-manufacturing firms. To do this, a number of different financials had to be obtained for each of our sample companies from a large up to date dataset. From these financials, ratio analysis was performed and variables were examined to test their impact upon the Altman Z-Score and Ohlson O-Score. Different combinations of these variables were tested to analyze their significance upon both our predictive models.

Numerous studies completed in the past including both Altman (1968) and Ohlson (1980) used solely publicly listed company financials to generate the results to their studies. This study utilizes the available information from exclusively private institutions to assess a possibility ofthe use of $\mathrm{Z}$ and $\mathrm{O}$ Score models for relevant prediction of public and private companies.

Due to the inaccessibility of private company financials, this study will aim to add to the limited existing pool 
of literature, analyzing both the $\mathrm{Z}$ and $\mathrm{O}$ Scores upon private companies.

\section{The aim and objectives of research}

The aim of the study is to assess the area of Corporate Financial Failureon the basis of application of two Models:

1. The Altman Z-Score Private Firm Model.

2. The Ohlson O-Score Model.

In completing this study in corporate failure, the objective of this article is to provide insight into two areas. Firstly, as to whether the ageing corporate failure prediction models developed by Altman and Ohlson can be seen as accurate today on private non-manufacturing companies. Secondly, this study analyses the significance of a number of variables using statistical software to test their impact upon both our corporate failure prediction models. Corporate failure can be prevented if it is identified early and preventative measures are taken. Decision makers need to act quickly when the company is heading towards distress to prevent a decline. As such, this only further emphasizes the value that corporate failure predicting models can have upon a company. With extensive research already conducted on large publicly listed companies, this study of smaller private companies will add to the somewhat limited body of research in this area.

\section{Literature review}

As identified in previous studies by Gertner and Shwarfstein (1991) [3] and Giammarino (1989) [4], the closer of a company gets to corporate failure the more expensive corporate restructuring becomes and the more difficult failure to avoid it.

In support of this, Gilson (1990) [5] ascertains that the cost of restructuring for a company that is not in financial distress is fractional in comparison to one that is in corporate distress. As such, the further in advance that corporate failure can be predicted, the less likely the company will be fail and the less expensive company restructuring will be proves. As demonstrated by Hunter (2002) [6], the corporate failure of a company is often abrupt and unexpected. In many cases companies, which may have been performing strongly, have a change in their business environment and rapidly decline the performance level. Likewise, there are plenty of examples of companies that have been on the verge of corporate failure for extended periods of time and have continued to survive against all probability. Uncertainty in the business environment is a challenge for any company and so sourcing ways to help predict financial distress presents an intriguing area to study.

\section{Materials and methods of research}

The majority of studies in the area of corporate failure have used public company datasets rather than private company datasets. This study, through using a solely private company dataset contributes to the limited pool of studies, analyzing private corporate failure rather than public company corporate failure.Numerous studieshave conducted an analysis upon the original Altman Z-Score Model but there is far less that have used Altman more recent Private Firm Model. This study tests the predictive capabilities of the Altman Z-Score Private Firm Model along with the Ohlson O-Score Model upon four years of private company data. Both the Altman Z-Score Private Firm Model and the Ohlson O-Score Model are originally designed for use upon companies operating within manufacturing industries. This study tests both these models upon companies operating in non-manufacturing industries to assess whether they predict corporate failure with similar levels of accuracy.

\section{Research results}

The research is based on the analysis of 4 years full financial data of 100 Companies in total: 50 failed companies and 50 non-failedcompanies. The following criteria are taken into consideration: private, non-manufacturing, non-financial company, based in the well - developed financial market. The following Altman Z-Score Private Firm Model is used:

$$
\mathrm{Z}=0,717 \mathrm{~T} 1+0,847 \mathrm{~T} 2+3,107 \mathrm{~T} 3+0,420 \mathrm{~T} 4+0,998 \mathrm{~T} 5 .
$$

Presented multi-factor model is plannedto give an indication of corporate failure.

Above model is mostly used for private firms assessment. Adaptation from the original model is presented based on accounting ratios from company financial data.

Altman Z-Score private firm Model components are:

$\mathrm{T} 1=($ Current Assets - Current Liabilities $) /$ Total Assets; $\mathrm{T} 2$ = Retained Earnings / Total Assets;

T3 = Earnings Before Interest and Taxes / Total Assets; $\mathrm{T} 4$ = Book Value of Equity / Total Liabilities;

$\mathrm{T} 5=$ Sales $/$ Total Assets.

Altman Z-Score Private Firm Model Parameters are:

$Z^{\prime}>2,9-\ll$ Safe» Zone;

$1,23<Z^{\prime}<2,9-\ll$ Grey» Zone;

$Z^{\prime}<1,23-\ll$ Distress» Zone.

Ohlson O-Score model components are:

$$
\begin{aligned}
& T=-1,32-0,407 \ln \left(T A_{T}\right)+6,03 \frac{T L_{T}}{T A_{T}}- \\
& -1,43 \frac{W C_{T}}{T A_{T}}+0,0757 \frac{C L_{T}}{C A_{T}}- \\
& -1,72 X-2,37 \frac{N I_{T}}{T A_{T}}-1,83 \frac{F F O_{T}}{T L_{T}}+0,285 Y- \\
& -0,521 \frac{N I_{T}-N I_{T-1}}{\left|N I_{T}\right|+\left|N I_{T-1}\right|} .
\end{aligned}
$$

Multi-factored model is used to indicate corporate failure. It is derived from a 2000 company studied by Ohlson (1980) and based on accounting ratios from company financial data:

$$
\begin{aligned}
& \mathrm{TA}=\text { Total Assets; } \\
& \mathrm{X}=1 \text { if } \mathrm{TL}>\mathrm{TA}, 0 .
\end{aligned}
$$

Otherwise:

$\mathrm{TL}=$ Total Liabilities;

$\mathrm{WC}=$ Working Capital; 
$\mathrm{CL}=$ Current Liabilities;

$\mathrm{NI}=$ Net Income;

$\mathrm{CA}=$ Current Assets;

$\mathrm{FFO}=$ Funds From Operations;

$\mathrm{Y}=1$ if a Net Loss for the last two years, 0 otherwise.

The following data are received (Table 1, Table 2).

Table 1

For Altman Z-Score Private Firm Model

\begin{tabular}{|c|c|}
\hline Year & Accuracy Level \\
\hline T-1 & $57 \%$ \\
\hline T-2 & $57 \%$ \\
\hline T-3 & $52 \%$ \\
\hline T-4 & $42 \%$ \\
\hline
\end{tabular}

For Ohlson 0-Score Model

Table 2

\begin{tabular}{|c|c|}
\hline Year & Accuracy Level \\
\hline T-1 & $46 \%$ \\
\hline T-2 & $44 \%$ \\
\hline T-3 & $57 \%$ \\
\hline T-4 & $49 \%$ \\
\hline
\end{tabular}

The study found that the accuracy levels of both the Altman Z-Score Private Firm Model and the Ohlson O-Score Model were relatively low across the study.

\section{SWOT-analysis of research results}

\section{Strengths:}

Research has strongly suggested that the Altman Z-Score Model and the Ohlson O-Score Model have merit in predicting the bankruptcy of manufacturing companies, this is uncontested and a trend amongst corporate failure literature.

Weaknesses:

A weakness identified from this point, however, is in each of the cited papers where an analysis has been conducted, the tested companies have all been from within the same market or country. This is seen to be the case with Machek (2014) [7], who uses the Czech Republic, Moghadam (2013) [8], who uses solely Iranian listed companies and Hunjra (2013) [9], who uses the Karachi Stock Exchange. This represents a minor weakness in the past literature of corporate failure and is an area that could be tackled in the future.

Opportunities:

Opportunities were revealed by Tsai (2012) [10], who correctly showed how the Altman Z-Score variables were easily interpreted in relation to credit ratings. Given credit ratings are meant to be independent and stand alone, if a company can manipulate its figures for the purposes of an upgraded rating, this would appear to defeat the ratings purpose entirely.

Threats:

Research into the area of corporate failure produced numerous studies completed using the original Altman Z-Score Model but far less utilizing the Altman Z-Score Private Firm Model. An additional identified trend is the use of the Altman Z-Score Model and the Ohlson O-Score Model in conjunction with other models when determi- ning the likelihood of company corporate failure. Chan Lau (2006) [11] is an example of this, where the macro stress test model developed by Virolainen (2004) [12] is used with the Altman Z-Score Model to provide a more accurate probability of default than just using the Altman Z-Score Model alone.

\section{Conclusions}

1. Our conclusion of the study is the following: neither the Altman Z-Score Private Firm Model nor the Ohlson O-Score Model can be used as an accurate predictor of corporate failure on private companies operating outside of the manufacturing sector. Neither model in any of the four years of company financials that were tested was able to generate an overwhelming result of correct specifications.

2. In the variable analysis conducted by this study, results proved to be convincing and in line with expectations formed from past literature. Five from the six variables chosen proved to be significant upon the Altman Z-Score Private Firm Model and the variable «Industry of the Company» along with «Size of the Company» was seen to be significant upon the Ohlson O-Score Model.

\section{References}

1. Altman, E. Financial Ratios, Discriminant Analysis and the Prediction of Corporate Bankruptcy [Text] / E. Altman / Journal of Finance. - 1968. - Vol. 23, № 4. - P. 589-609. doi: $10.2307 / 2978933$

2. Chan-Lau, J. A. Fundamentals-based estimation of default probabilities: A survey [Text] / J. A. Chan-Lau // IMF Working Papers. 2006. - Vol. 6, № 149. - P. 1. doi:10.5089/9781451864090.001

3. Gertner, R. A Theory of Workouts and the Effects of Reorganization Law [Text] / R. Gertner, D. Schwarfstein // The Journal of Finance. - 1991. - Vol. 46, № 4. - P. 1189-1222. doi:10.1111/j.1540-6261.1991.tb04615.x

4. Giammarino, R. M. The Resolution of Financial Distress [Text]/ R. M. Giammarino // The Review of Financial Studies. 1989. - Vol. 2, № 1. - P. 25-47. doi:10.1093/rfs/2.1.25

5. Gilson, S. C. Bankruptcy, boards, banks, and blockholders [Text] / S. C. Gilson // Journal of Financial Economics. - 1990. Vol. 27, № 2. - P. 355-387. doi:10.1016/0304-405x(90)90060-d

6. Ijaz, M. Sh. Assessing the Financial Failure Using Z-Score and Current Ratio: A Case of Sugar Sector Listed Companies of Karachi Stock Exchange [Electronic resource] / M. Sh. Ijaz, A. I. Hunjra, Z. Hameed, A. Maqbool, Rauf-i-Azam // World Applied Sciences Journal. - 2013. - № 23 (6). - P. 863-870. Available at: \www/URL: http://wwwidosi.org/wasj/wasj23(6)13/ 21.pdf. doi:10.5829/idosi.wasj.2013.23.06.2243

7. Wade, R. H. Failing States and Cumulative Causation in the World System [Text] / R. H. Wade // International Political Science Review/Revue internationale de science politique. - 2005. Vol. 26, № 1. - P. 17-36. doi:10.1177/0192512105047894

8. Machek, O. Long-term Predictive Ability of Bankruptcy Models in the Czech Republic: Evidence from 2007-2012 [Text] / O. Machek // Central European Business Review. - 2014. Vol. 3, № 2. - P. 14-17. doi:10.18267/j.cebr.80

9. Moghadam, A. G. Review of the Prediction Power of the Altman and Ohlson Models in Predicting Bankruptcy of Listed Companies in Tehran Stock Exchange - Iran [Electronic resource] / A. G. Moghadam, F. N. Zadeh, M. M. G. Fard // Houston Business Journal. - 2003. - Available at: \www/ URL: http://www.mbaforum.ir/download/mba/m/7th/236.pdf

10. Ohlson, J. A. Financial Ratios and the Probablistic Prediction of Bankruptcy [Text] / J. A. Ohlson // Journal of Accounting Research. - 1980. - Vol. 18, № 1. - P. 109-131. doi: $10.2307 / 2490395$

11. Chen, Y.-S. Applying recurrent event analysis to understand the causes of changes in firm credit ratings [Text] / Y.-S. Chen, P.-H. Ho, C.-Y. Lin, W.-C. Tsai // Applied Financial Economics. - 2012. - Vol. 22, № 12. - P. 977-988. doi:10.1080/ 09603107.2011.633888 
12. Virolainen, K. Macro Stress Testing with a Macroeconomic Credit Risk Model. Bank of Finland [Electronic resource] / K. Virolainen // SSRN Electronic Journal. - Available at: \www/ URL: https://doi.org/10.2139/ssrn.622682

\section{ПРОБЛЕМЫ ПРОГНОЗИРОВАНИЯ БАНКРОТСТВА} НЕПРОИЗВОДСТВЕННЫХ КОМПАНИЙ

В работе выявлены возможности использования скоринговых моделей Альтмана и Олсона в целях прогноза банкротства непроизводственных компаний в горизонте операционного периода 1-4 года. Исследование раскрывает особенности применения указанных моделей в целях оценки устойчивости компаний.

Ключевые слова: модель Альтмана Z-скоринг, модель Олсона О-скоринг, непроизводственные компании, банкротство корпорации.

Ярыгина Ирина Зотовна, доктор экономических наук, профессор, кафедра мировой экономики и мировых финансов, Финансовый университет при Правительстве Российской Федерации, Москва, Российская Федеращия, e-mail: jiz4@yandex.ru.
О’Мэлли Патрик, кафедра мировой экономики и мировых финансов, Финансовый университет при Правительстве Российской Федерации, Москва, Российская Федерация,

e-mail: patrick.o-malley@ucdconnect.ie.

Яригіна Ірина Зотовна, доктор економічних наук, професор кафедра світової економіки $і$ світових фінансів, Фінансовий університет при Уряді Російської Федерацї, Москва, Російська Федерація.

О’Меллі Патрік, кафедра світової економіки $і$ світових фiнансів, Фінансовий університет при Уряді Російської Федерації, Москва, Російська Федерація.

Yarygina Irina, Financial University under the Government of the Russian Federation, Moscow, Russian Federation, e-mail: jiz4@yandex.ru.

O'Malley Patrick, Financial University under the Government of the Russian Federation, Moscow, Russian Federation,

e-mail: patrick.o-malley@ucdconnect.ie

\section{Dohrovol'ska 0.}

\section{ANALYSIS OF CREDIT COOPERATION IN THE CURRENT ECONOMIC SPACE}

Обгрунтовано можливі напрями розвитку кредитної кооперащії та виокремлено основні віхи становлення кредитних спілок в Україні. Досліджено тенденщї розвитку кредитних спілок $і$ визначено пріоритетні напрями іх діяльності у майбутньому. Проведено аналіз стану кредитних спілок України, акцентовано увагу на розбудову трирівневої кооперативної кредитної системи в порівнянні зі світовим досвідом.

Ключові слова: кооперація, кредит, кредитна спілка, комериійний банк, фінансова установа, кооперативний банк, фінансове забезпечення.

\section{Introduction}

In a developed society, financial services are not less important than production. The most actively develops that segment of a service, which is related to the needs of social production and consumption, as well as financial and credit services, insurance services and more. One of the participants of the financial market is a savings and credit cooperatives - credit unions, which Ukraine has always been a form of self-organizing community.

The history of credit relations in Ukraine made up on the basis of those credit relationships that existed in the Soviet Union. Transition from a planned to a market economic system in the field of credit relationships was implemented faster than in other areas of our country. The reason is that the basis of this relationship is the most mobile resource - money.

Today it is particularly important as the growing number of financial intermediaries and improving the efficiency of their activities; it is important to develop not only banks but also other financial institutions of different types, to ensure the full functioning of the financial infrastructure that will serve as the key to economic growth. Problems of credit unions are more acute in the financial crisis and the crisis of the banking system of Ukraine. All this determines the relevance and need for research on the current state and further development of credit unions.

\section{The object of research and its technological audit}

A study of possible development directions of credit cooperatives for current challenges of economic space is conducted for effective formation. Modern credit cooperatives are the two most common types: cooperative banks (mostly in Europe) and credit unions (in most parts of the world) and are credit and cooperative sector of the economies of many countries.

The proposed model for developing three-level cooperative credit system in Ukraine provides phased expansion of the market mandate for credit unions in corporate lending and the provision of financial services, creation of credit cooperatives, central and local cooperative banks and other elements of the system that are addressing the whole spectrum of problems, in particular the system of guarantees and deposit insurance system to support the financial stability of credit unions, credit bureaus, centers of information technology, service infrastructure that would ensure minimizing risk and entry of credit unions in payment systems, educational infrastructure and so on. 